\title{
Anar Azizov,
}

Ph.D., Associate Professor, Azerbaijan Cooperation University, Azerbaijan

ORCID ID, 0000-0002-8183-305X

email: azizovanarali@gmail.com

\section{INNOVATION DEVELOPMENT AND ENTREPRENEURSHIP MANAGEMENT IN TOURISM OF AZERBAIJAN: CURRENT TRENDS AND PRIORITIES}

Abstract. The article examines modern trends and priority areas of innovation development of entrepreneurship in tourism of Azerbaijan, considering national peculiarities and European trends in the tourism market. The author focused on the importance of tourism, its accessibility, and socially responsible entrepreneurship in tourism services in the sustainable development of society and the achievement of its goals. The economic effect from the tourism sector development was substantiated. Special emphasis was placed on the role and key aspects of tourism digitalization and management innovations in tourism services. At the same time, the systematization of scientific research and developments on these issues indicated the absence of a unified approach to assessing the impact of the innovation development of entrepreneurship in the tourism sector on the country's macro indicators. The main aim of the article is to study, on the one hand, the impact of increasing the tourism development level on economic growth, and on the other, innovation activity on the competitiveness of the tourism sector (based on the experience of the EU countries and Azerbaijan). The information base contains statistical and analytical data of the World Bank, World Intellectual Property Organization, World Tourism Organization, World Economic Forum. The work analyzed the main trends of the tourism services market to achieve the set goals. A SWOT analysis was carried out to determine the market's strengths and weaknesses, opportunities, and threats. The key directions in the management of innovation development of entrepreneurship in tourism were characterized based on the assertion of the need to promote successful innovations in tourism and the entrepreneurial ecosystem through the stakeholders' interaction. Special attention was paid to the growing role of the state in increasing the innovation activity of tourism entrepreneurship, especially in the face of the negative consequences of the COVID-19 pandemic. The Arellano-Bond dynamic regression model for assessing panel data was built to empirically confirm and formalize the positive impact of the tourism development increase (based on the indicators of the share of the revenue from tourism services in total exports, the number of tourists arriving, and the number of tourist departures) on the economic growth of EU countries and Azerbaijan (expressed in GDP per capita growth). Its quality was checked using the Sargan test employing the STATA 14.2 software package. The interrelation of the studied indicators was preliminarily characterized according to the correlation analysis (Shapiro-Wilk test, calculation of Pearson / Spearman correlation coefficients with time lags). A comparative correlation and regression analysis regarding the influence of the $E U$ countries and Azerbaijan readiness for information and communication technologies and the innovation development in general on the tourism sector competitiveness of the countries was carried out. Attention is focused on the fact that one should not dwell only on innovations in ICT in tourism and its digitalization. It is necessary to develop financial, insurance, marketing, managerial, administrative, medical, socio-cultural, environmental, and other innovations in tourism, which today are closely connected and complementary to each other.

Keywords: state policy, innovation in tourism, tourism competitiveness, innovation management, entrepreneurship in tourism, sustainable tourism, financing innovation, digitalization of tourism.

Introduction. In modern society, tourism is an integral part of the life of citizens and, at the same time, an essential type of economic activity. The importance of tourism and, accordingly, the development of entrepreneurship in the tourism sector could hardly be overestimated, since tourism contributes to the employment of the population and the economic growth of the country, the development of infrastructure, especially in rural areas, the preservation and augmentation of the cultural and natural wealth of countries.

Given the COVID-19 pandemic with a significant economic impact on developing and developed countries globally, the tourism services sector suffered significant losses. First, they were caused by the

Cite as: Azizov, A. (2021). Innovation Development and Entrepreneurship Management in Tourism of Azerbaijan: Current Trends and Priorities. Marketing and Management of Innovations, 4, 104-120. http://doi.org/10.21272/mmi.2021.4-09

104 

Priorities

quarantine restrictions of the countries' governments regarding entry and exit into the country, public health, their expectations and concerns, and the citizens' financial well-being. Thus, in 2020, revenue from international tourism worldwide amounted to 533.5 billion US dollars, $63.6 \%$ less than in the previous year (in 2019 - 1465.8 billion US dollars). At the same time, the share of tourism in total exports decreased to $3 \%$ or 636 billion US dollars (in $2019-7 \%$ or 1716.2 billion US dollars). International tourist arrivals also decreased by $73 \%$ to 402.1 million (in 2019 - 1,466.1 million). In addition, nearly 100 million tourism jobs were at risk. In Azerbaijan, according to data for 2020, revenue from international tourism was recorded at the level of 0.3 billion US dollars, $83.3 \%$ less than the previous year (in $2019-1.8$ billion US dollars). The share of tourism in total exports decreased by $85 \%$ to $2 \%$ or 0.3 billion US dollars (in $2019-9 \%$ or 2 billion US dollars) (UNWTO, 2020). The dynamics of these indicators testify to negative trends in the tourism sector (for Azerbaijan, the consequences are more significant than the world average). Therefore, tourism resumption, digitalization, and innovative development are important components of economic recovery and growth, achieving the Sustainable Development Goals (UNDESA, SDG).

The article aims to study the impact of increasing the level of tourism development on economic growth and innovative activity on the competitiveness of the tourism sector (based on an analysis of the experience of the EU countries and Azerbaijan).

Literature Review. The issue of tourism as one of the popular areas of entrepreneurship is not new in the scientific literature (Ateljevic and Page, 2009; Comerio and Strozzi, 2018; Hallak et al., 2015; Jaafar et al., 2011; Işık et al., 2019; Lordkipanidze et al., 2005; Navickiene et al., 2015; Ratten, 2019; Schiopu et al., 2015; Tleuberdinova, 2021, etc.). However, the rapid innovative development and digitalization of the economy, global financial and economic, political and legal, socio-cultural and environmental changes, and social challenges and expectations, for example, related to the COVID-19 pandemic, again actualize the topic of innovative business development in tourism. This aspect is essential in developing countries, which are more sensitive to various global shocks. Karaoulanis and Vasiliki (2018) studied the problem of tourism in developing countries, focusing on the impact of tourism development in such countries on the income level of the local population to reduce poverty in developing countries.

Tiagoa et al. (2021), in the same context, analyzed sustainable tourism, sustainable digital communication for small and medium-sized hotel companies, environmentally friendly products, and sound practices. In addition to sustainability, one of the current trends is inclusiveness (George, 2020), the paradigm of inclusive economic development, corporate social responsibility in the tourism sector (Taliouris and Trihas, 2017). The strategic and operational implementation of ICT and the e-tourism emergence as a field of tourism and hospitality, and the impact of ICT on the tourism and hospitality industry in London are reflected in work (Khan and Hossain, 2018). The digital problems and the effect of COVID-19 on business sector activity are observed in the research (Tiutiunyk et al., 2021; Boronos et al., 2020). Bouronikos (2021) analyzed digital technologies in tourism, including mobile technologies, augmented and virtual reality, fintech, and contactless payments, and a special Flexi-Tour project from Erasmus + to train tourism managers and specialists in the current market and tourism business requirements using technological innovation. Dehtjare (2018) identified the key drivers of digitalization in the modern hospitality industry, leading to the innovative development of the tourism industry. Natocheeva et al. (2020) also considered the issue of the digitalization development in tourism, the motives of the tourism market subjects to use digital technologies, and in particular, the marketing role in tourism in the Republic of Kazakhstan. Letunovska et al. (2020) paid attention to the health tourism marketing, Rubanov and Marcantonio (2017) - to online alternative financing platforms relevant to the tourism sector. The problem of tourism digitalization is also reflected in the works (Wörndl et al., 2021; Opute et al., 2020; Khurramov, 2020; Mofokeng and Matima, 2018; Zsarnoczky, 2018, etc.). Das and Naskar (2018) examined the relationship between tourism development and infrastructure as a determinant and a prerequisite for economic growth in general. Particular attention was paid to direct and indirect forms of 

Priorities

government intervention to ensure the protection of natural resources and equitable distribution of economic benefits from tourism development, stimulation of private sector to encourage financial investment in sustainable tourism, encourage cooperation and interaction between various actors in this process. However, Saberifar et al. (2019) discussed tourist satisfaction, assessing modern infrastructure, socio-cultural and environmental conditions in the sustainable development of the tourism industry, and tourism management.

Despite the significant scientific heritage, the relationship between the innovative development of entrepreneurship in the tourism sector and its competitiveness, their effect on economic growth based on the experience of the EU countries, particularly Azerbaijan, has practically not been studied.

Methodology and research methods. A complex of general theoretical and special scientific methods was applied (factorial and comparative analysis, graphical and statistical analysis, synthesis and systematization, induction and deduction, analytical analysis, etc.) to achieve the set goals and objectives of the research. The current state, trends, and priority directions of innovative development of entrepreneurship in tourism in Azerbaijan were substantiated based on the results of dynamic and graphical analysis of data for Azerbaijan and 27 EU countries for 2009-2020, correlation analysis with preliminary Shapiro-Wilk test for compliance with the law of normal distribution. Based on it, the method for calculating the Pearson or Spearman correlation coefficient was chosen, considering possible time lags, using the Excel and STATA software. A SWOT analysis was used to determine the tourism market's strengths, weaknesses, opportunities, and threats. The regression analysis, construction of linear regression models, formalization of the obtained results empirically confirmed that with an increase in the country's readiness for ICT by $1 \%$, the level of competitiveness of the country's tourism and travel sector would increase by an average of $0.49 \%$. An increase in the level of the country's innovative development by $1 \%$ leads to a rise in the level of competitiveness of the country's tourism and travel sector by an average of $0.72 \%$.

Based on a sample of data for Azerbaijan and 18 EU countries for the period 2010-2019 (the limited time and the number of EU countries included in the sample are due to the publicly available statistical data on the studied indicators), a dynamic model for assessing Arellano-Bond panel data was built. The quality of this model was verified using the Sargan test employing the STATA 14.2 software package. It has been empirically confirmed that an increase in the level of tourism development (based on indicators of proceeds from tourism services in total exports, the number of tourists arriving, and the number of tourist flights) leads to an increase in the country's GDP per capita.

Results. Today, the global goal of innovative business development in the tourism sector is to promote socially responsible, sustainable, and accessible tourism for inclusive growth. In this regard, more new directions of entrepreneurship appear in tourism, namely: recreational, health-improving, gastronomic, agritourism; ethnic, historical, ecological, cultural, religious, active, adventure, educational, sports tourism, digital tourism, etc. At the same time, such auxiliary areas of entrepreneurship in tourism as transport and transfer services, hotel, restaurant business, and other various service and entertainment services.

In turn, in Azerbaijan, based on its national peculiarities (natural resources and beautiful protected areas, recreational sea and mountainous areas, medical sanatoriums of Naftalan, centuries-old historical and cultural monuments, famous cities, interesting excursion routes, bright folk traditions, and festivals, in including gastronomic and shopping festival) the priority areas of entrepreneurship in tourism should consist of: gastronomic, health, historical, cultural, ecological, mountain, hunting, fishing, and shopping tourism. Despite its wide popularity and rapid development, the tourism market is characterized by strengths and weaknesses. A SWOT analysis was carried out to determine the opportunities and threats, strengths, and weaknesses of entrepreneurship in tourism in Azerbaijan (Table 1). 
A. Azizov. Innovation Development and Entrepreneurship Management in Tourism of Azerbaijan: Current Trends and Priorities

Table 1. SWOT analysis of strengths, weaknesses, opportunities, and threats of entrepreneurship in tourism of Azerbaijan

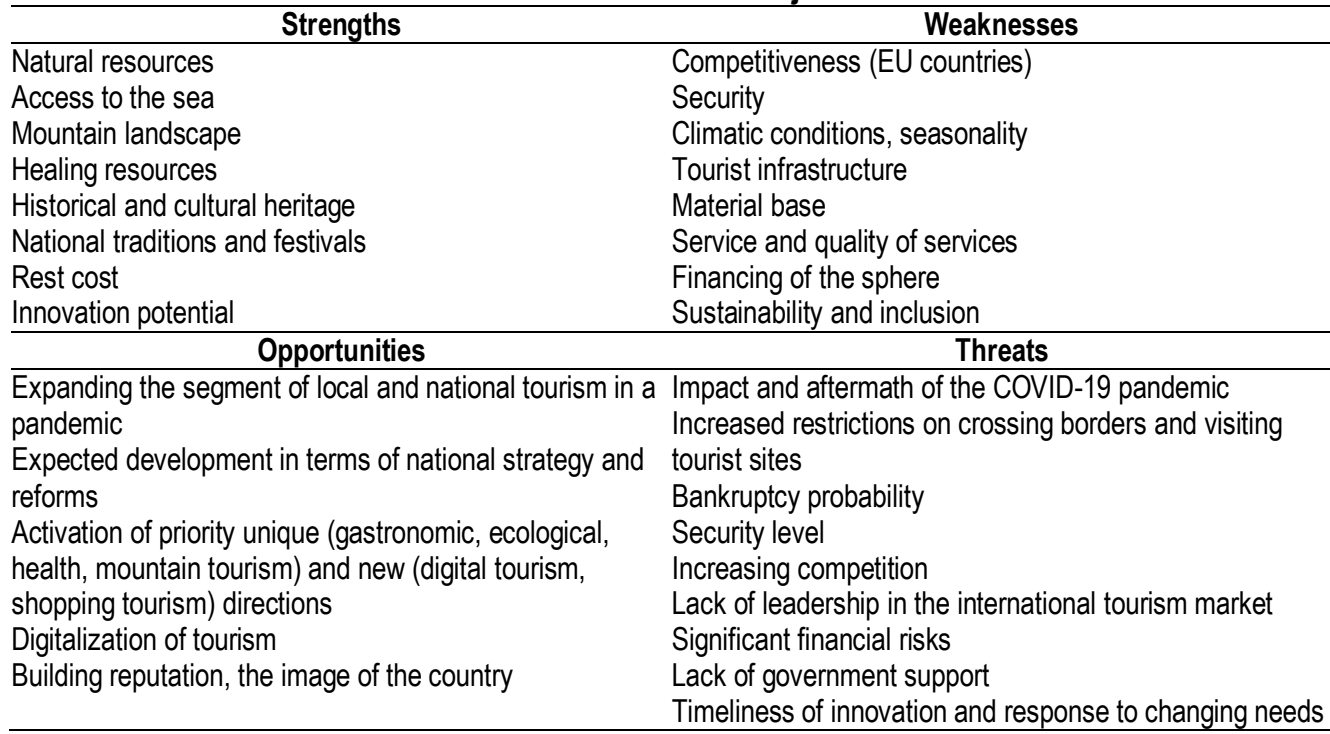

Sources: developed by the author.

The most effective and timely use of the described potential opportunities of tourism entrepreneurship and hedging possible threats in this area depends on the management effectiveness and the adequacy of its tools to our time realities. Therefore, among the key areas in the management of innovative development of entrepreneurship in tourism are as follows:

1) a socially-oriented partnership based on the assertion of the need to promote successful innovations in tourism and the entrepreneurial ecosystem through the interaction of various stakeholders such as government, business, citizens, educational and cultural institutions, investors, innovative firms, international and European organizations (UN World Tourism Organization, OECD, etc.);

2) consideration of the sustainable development goals and tourism inclusiveness in governance at various levels;

3) increasing the local management efficiency of the tourism sector, primarily in territorial communities;

4) digitalization of tourism, implementation of digital business communications, development of online travel platforms and services, etc.;

5) improving the safety of tourist services (physical safety of tourists, cyber security);

6) management and insurance of risks;

7) search and use of alternative financial resources in the development of tourism business, especially during a pandemic;

8) adaptive planning and forecasting for different time periods, application of the scenario approach;

9) customer-centrism and flexibility of management, quick response to changing requests and customers' needs, the availability of effective feedback (including due to digital technologies);

10) development of new directions, types, and forms of tourist services. 
A. Azizov. Innovation Development and Entrepreneurship Management in Tourism of Azerbaijan: Current Trends and Priorities

As a result of the COVID-19 pandemic, regulatory changes, and health concerns, tour operators and travel agencies develop innovative entrepreneurship management strategies to reclaim and expand their customer segment. It is worth paying attention to the following managerial innovations:

1) organizing socially distant travel, reducing group travel, and expanding the range of unaccompanied travel or a fixed package of services;

2) engaging travel experts;

3) readiness and timely adaptation to changing transport expectations of customers;

4) development of digital business communications through social networks, online services, and online stores, directly developing travel sites and managing social networks, planning and managing digital presence, etc.

Nowadays, among the key innovative and digital trends in the travel and tourism industry, robotization, cybersecurity technologies, big data processing, smart control, the use of voice control and search, virtual and augmented reality, recognition technologies, contactless payments, the Internet of things, artificial intelligence are rightly distinguished, including chatbots with artificial intelligence, etc. (Knowledge Platform). During the COVID-19 pandemic, which has negatively affected and continues to affect the tourism business, the state's role in increasing the innovative activity of the tourism business is growing. The main directions of state support for tourism entrepreneurship should be budget financing of tourism and culture, which, as a rule, are carried out on a leftover basis. Besides, it is tax (tax incentives, tax holidays) and monetary (affordable and/or preferential consumer and mortgage loans) stimulating innovation in tourism, attracting businesses, investors, and start-ups in this area. The state's strategic planning for developing tourism at the local, national and international levels, and, accordingly, real support for projects and start-ups aimed at the practical development of this area, is of great importance. Direct government subsidies during the crisis period should cover hotels and travel companies and all those tourism infrastructure facilities that are on the verge of bankruptcy during a pandemic and need financial assistance. In addition, support from the state is also important based on the national economy from the tourism development. We analyze the impact of tourism development indicators on the country's economic growth based on data for Azerbaijan and 18 EU countries for 2010-2019 (the limited time and the number of EU countries included in the sample are due to the availability of publicly available statistical data on the studied indicators). Table 2 presents data on the annual growth of the gross domestic product.

Table 2. Annual growth of the gross domestic product in Azerbaijan and EU countries for 2010-

\begin{tabular}{|c|c|c|c|c|c|c|c|c|c|c|}
\hline \multicolumn{11}{|c|}{$2019, \%$} \\
\hline Country & 2010 & 2011 & 2012 & 2013 & 2014 & 2015 & 2016 & 2017 & 2018 & 2019 \\
\hline 1 & 2 & 3 & 4 & 5 & 6 & 7 & 8 & 9 & 10 & 11 \\
\hline Azerbaijan & 3,55 & $-2,85$ & 0,85 & 4,48 & 1,52 & $-0,15$ & $-4,14$ & $-0,82$ & 0,62 & 1,62 \\
\hline Belgium & 1,93 & 0,38 & 0,12 & $-0,01$ & 1,13 & 1,45 & 0,76 & 1,23 & 1,33 & 1,24 \\
\hline Bulgaria & 1,22 & 3,01 & 0,94 & 0,89 & 2,47 & 4,66 & 4,55 & 4,26 & 3,84 & 4,43 \\
\hline Cyprus & $-0,62$ & $-2,13$ & $-4,91$ & $-6,34$ & $-0,74$ & 3,81 & 5,95 & 4,18 & 3,96 & 1,69 \\
\hline Czechia & 2,14 & 1,55 & $-0,92$ & $-0,08$ & 2,15 & 5,18 & 2,34 & 4,89 & 2,85 & 2,62 \\
\hline Germany & 4,34 & 5,87 & 0,23 & 0,16 & 1,78 & 0,62 & 1,41 & 2,30 & 0,78 & 0,83 \\
\hline Denmark & 1,42 & 0,92 & $-0,15$ & 0,51 & 1,11 & 1,62 & 2,44 & 2,16 & 1,49 & 1,75 \\
\hline Finland & 2,71 & 2,07 & $-1,87$ & $-1,36$ & $-0,78$ & 0,21 & 2,52 & 2,95 & 1,01 & 1,23 \\
\hline France & 1,45 & 1,70 & $-0,17$ & 0,06 & 0,48 & 0,75 & 0,83 & 1,99 & 1,59 & 1,62 \\
\hline Greece & $-5,60$ & $-10,02$ & $-6,58$ & $-2,03$ & 1,37 & 0,25 & $-0,08$ & 1,48 & 1,77 & 1,96 \\
\hline Croatia & $-1,09$ & 0,15 & $-2,09$ & $-0,17$ & 0,07 & 3,28 & 4,22 & 4,69 & 3,73 & 3,43 \\
\hline Hungary & 1,35 & 2,23 & $-0,87$ & 2,14 & 4,51 & 4,07 & 2,44 & 4,59 & 5,53 & 4,69 \\
\hline Ireland & 1,20 & 0,63 & $-0,47$ & 0,74 & 7,92 & 24,00 & 0,90 & 7,76 & 7,69 & 3,49 \\
\hline Luxembourg & 2,97 & 0,29 & $-2,72$ & 1,29 & 1,87 & 1,87 & 2,34 & $-0,64$ & 1,14 & 0,31 \\
\hline
\end{tabular}


A. Azizov. Innovation Development and Entrepreneurship Management in Tourism of Azerbaijan: Current Trends and Priorities

\begin{tabular}{lcccccccccc} 
& & \multicolumn{1}{c}{} & \multicolumn{1}{c}{ Continued Table 2 } \\
\hline $\mathbf{1}$ & $\mathbf{2}$ & $\mathbf{3}$ & $\mathbf{4}$ & $\mathbf{5}$ & $\mathbf{6}$ & $\mathbf{7}$ & $\mathbf{8}$ & $\mathbf{9}$ & $\mathbf{1 0}$ & $\mathbf{1 1}$ \\
\hline Poland & 4,04 & 4,70 & 1,33 & 1,19 & 3,46 & 4,31 & 3,19 & 4,82 & 5,35 & 4,57 \\
Portugal & 1,69 & $-1,55$ & $-3,67$ & $-0,38$ & 1,34 & 2,21 & 2,34 & 3,76 & 3,01 & 2,46 \\
Romania & $-3,33$ & 2,41 & 2,50 & 4,16 & 4,00 & 3,44 & 5,31 & 7,94 & 5,09 & 4,68 \\
Slovakia & 5,77 & 2,71 & 1,72 & 0,56 & 2,54 & 4,72 & 2,00 & 2,83 & 3,51 & 2,37 \\
Slovenia & 0,90 & 0,65 & $-2,84$ & $-1,16$ & 2,67 & 2,13 & 3,12 & 4,75 & 4,04 & 2,53 \\
\hline
\end{tabular}

Sources: developed by the author based on (The World Bank, 2019).

Tables 3-5 provide individual indicators of the tourism sector's development. Table 2 shows the indicators of the number of tourists who arrived in the country.

Table 3. The number of tourists arriving in Azerbaijan and the EU countries for 2010-2019, thousand people

\begin{tabular}{lcccccccccc}
\hline Country & $\mathbf{2 0 1 0}$ & $\mathbf{2 0 1 1}$ & $\mathbf{2 0 1 2}$ & $\mathbf{2 0 1 3}$ & $\mathbf{2 0 1 4}$ & $\mathbf{2 0 1 5}$ & $\mathbf{2 0 1 6}$ & $\mathbf{2 0 1 7}$ & $\mathbf{2 0 1 8}$ & $\mathbf{2 0 1 9}$ \\
\hline Azerbaijan & 1963 & 2239 & 2484 & 2509 & 2298 & 2006 & 2249 & 2697 & 2850 & 3170 \\
Belgium & 7186 & 7494 & 7560 & 7684 & 7887 & 8355 & 7481 & 8385 & 9119 & 9343 \\
Bulgaria & 8374 & 8713 & 8867 & 9192 & 9409 & 9317 & 10604 & 11596 & 12368 & 12552 \\
Cyprus & 2450 & 2626 & 2635 & 2626 & 2558 & 2780 & 3286 & 3750 & 4024 & 4117 \\
Czechia & 21941 & 22810 & 25750 & 26332 & 27166 & 29604 & 32519 & 34701 & 36268 & 36268 \\
Germany & 26875 & 28374 & 30411 & 31545 & 32999 & 34970 & 35555 & 37452 & 38881 & 39563 \\
Denmark & 26730 & 25811 & 26402 & 26516 & 28070 & 28209 & 28692 & 30736 & 30801 & 32903 \\
Finland & 3670 & 4192 & 4226 & 2797 & 2731 & 2622 & 2789 & 3180 & 3224 & 3290 \\
France & 189826 & 196595 & 197522 & 204410 & 206599 & 203302 & 203042 & 207274 & 211998 & 211998 \\
Greece & 20112 & 20112 & 20112 & 20112 & 24272 & 26114 & 28071 & 30161 & 33072 & 34005 \\
Croatia & 49006 & 49969 & 47185 & 48345 & 51168 & 55858 & 57587 & 59238 & 57668 & 60021 \\
Hungary & 39904 & 41304 & 43565 & 43611 & 45984 & 48345 & 52890 & 54962 & 57667 & 61397 \\
Ireland & 7134 & 7630 & 7550 & 8260 & 8813 & 9528 & 10100 & 10338 & 10926 & 10951 \\
Luxembourg & 805 & 874 & 950 & 945 & 1038 & 1090 & 1054 & 1046 & 1018 & 1041 \\
Poland & 58340 & 60745 & 67390 & 72310 & 73750 & 77743 & 80476 & 83804 & 85946 & 88515 \\
Portugal & 6756 & 7264 & 7503 & 9177 & 10497 & 11723 & 13359 & 15432 & 16186 & 17174 \\
Romania & 7498 & 7611 & 7937 & 8019 & 8442 & 9331 & 10223 & 10926 & 11720 & 12815 \\
Slovakia & 12583 & 12583 & 12583 & 12583 & 11556 & 14936 & 17376 & 15406 & 15406 & 15406 \\
Slovenia & 2049 & 2236 & 2377 & 2502 & 2675 & 3022 & 3397 & 3991 & 4425 & 4702 \\
\hline
\end{tabular}

Sources: developed by the author based on (The World Bank, 2019).

Table 4 presents the indicators of departures within international tourism in the EU countries and Azerbaijan.

Table 4. The number of departures within the framework of international tourism in the EU countries and Azerbaijan for 2010-2019, thousand

\begin{tabular}{lcccccccccc}
\hline Countries & $\mathbf{2 0 1 0}$ & $\mathbf{2 0 1 1}$ & $\mathbf{2 0 1 2}$ & $\mathbf{2 0 1 3}$ & $\mathbf{2 0 1 4}$ & $\mathbf{2 0 1 5}$ & $\mathbf{2 0 1 6}$ & $\mathbf{2 0 1 7}$ & $\mathbf{2 0 1 8}$ & $\mathbf{2 0 1 9}$ \\
\hline $\mathbf{1}$ & $\mathbf{2}$ & $\mathbf{3}$ & $\mathbf{4}$ & $\mathbf{5}$ & $\mathbf{6}$ & $\mathbf{7}$ & $\mathbf{8}$ & $\mathbf{9}$ & $\mathbf{1 0}$ & $\mathbf{1 1}$ \\
\hline Azerbaijan & 3176 & 3550 & 3874 & 4285 & 4244 & 4096 & 4282 & 4109 & 4908 & 5568 \\
Belgium & 8801 & 9727 & 9576 & 10803 & 10991 & 10835 & 13372 & 12142 & 13098 & 14191 \\
Bulgaria & 3676 & 3803 & 3758 & 3930 & 4158 & 4632 & 5392 & 6228 & 6699 & 7007 \\
Cyprus & 1246 & 1209 & 1194 & 1115 & 1209 & 1119 & 1268 & 1407 & 1446 & 1578 \\
Czechia & 8673 & 5279 & 5419 & 5781 & 5651 & 5856 & 6027 & 6775 & 7390 & 7346 \\
Germany & 85872 & 84692 & 82729 & 87459 & 83008 & 83737 & 90966 & 92402 & 108542 & 108542 \\
Denmark & 7726 & 7846 & 7843 & 6977 & 8528 & 8991 & 9651 & 8087 & 7475 & 10818 \\
\hline
\end{tabular}


A. Azizov. Innovation Development and Entrepreneurship Management in Tourism of Azerbaijan: Current Trends and Priorities

\begin{tabular}{|c|c|c|c|c|c|c|c|c|c|c|}
\hline \multicolumn{11}{|c|}{ Continued Table 4} \\
\hline 1 & 2 & 3 & 4 & 5 & 6 & 7 & 8 & 9 & 10 & 11 \\
\hline Finland & 7485 & 8238 & 9978 & 9526 & 9783 & 10022 & 10278 & 10480 & 10480 & 10440 \\
\hline France & 29973 & 31153 & 29642 & 30457 & 31941 & 30608 & 29636 & 44265 & 48069 & 49276 \\
\hline Greece & 3799 & 4941 & 4681 & 4594 & 5802 & 6291 & 7235 & 7685 & 7961 & 7848 \\
\hline Croatia & 5526 & 5526 & 5159 & 5444 & 4638 & 4355 & 2581 & 2597 & 2980 & 3500 \\
\hline Hungary & 16082 & 16634 & 16143 & 16038 & 16340 & 17276 & 18895 & 20297 & 22805 & 24860 \\
\hline Ireland & 6917 & 6514 & 6600 & 6579 & 6676 & 7094 & 7646 & 8171 & 8643 & 9350 \\
\hline Luxembourg & 1237 & 1643 & 1580 & 1624 & 1815 & 1702 & 1588 & 1802 & 1989 & 2548 \\
\hline Poland & 42760 & 43270 & 48290 & 52580 & 35400 & 44300 & 44500 & 46700 & 48600 & 50600 \\
\hline Portugal & 1361 & 1361 & 1361 & 1490 & 1502 & 1893 & 1941 & 2195 & 2486 & 3100 \\
\hline Romania & 10905 & 10936 & 11149 & 11364 & 12299 & 13118 & 16128 & 19953 & 21039 & 23066 \\
\hline Slovakia & 2692 & 3285 & 2689 & 2129 & 2406 & 2777 & 3095 & 3870 & 4662 & 5214 \\
\hline Slovenia & 5340 & 5073 & 4465 & 4440 & 4672 & 4909 & 5408 & 5410 & 5409 & 6049 \\
\hline
\end{tabular}

Sources: developed by the author based on (The World Bank, 2019).

Table 5 shows the indicators of proceeds from international tourism in the total exports of Azerbaijan and the EU countries for the study period.

Table 5. The share of receipts from international tourism in the total exports of Azerbaijan and the EU countries for $\mathbf{2 0 1 0 - 2 0 1 9 , \%}$

\begin{tabular}{lcccccccccc}
\hline \multicolumn{1}{c}{ Country } & $\mathbf{2 0 1 0}$ & $\mathbf{2 0 1 1}$ & $\mathbf{2 0 1 2}$ & $\mathbf{2 0 1 3}$ & $\mathbf{2 0 1 4}$ & $\mathbf{2 0 1 5}$ & $\mathbf{2 0 1 6}$ & $\mathbf{2 0 1 7}$ & $\mathbf{2 0 1 8}$ & $\mathbf{2 0 1 9}$ \\
\hline Azerbaijan & 2,81 & 4,05 & 7,18 & 7,29 & 8,33 & 12,66 & 16,24 & 16,20 & 11,10 & 8,48 \\
Belgium & 3,43 & 3,29 & 3,36 & 3,41 & 3,49 & 2,50 & 2,32 & 2,30 & 2,29 & 2,42 \\
Bulgaria & 15,05 & 12,63 & 12,17 & 12,26 & 12,24 & 11,03 & 12,07 & 11,73 & 11,61 & 10,96 \\
Cyprus & 16,52 & 17,63 & 18,88 & 19,97 & 19,15 & 18,16 & 19,42 & 19,49 & 18,13 & 18,11 \\
Czechia & 5,89 & 5,48 & 5,16 & 4,84 & 4,43 & 4,47 & 4,53 & 4,44 & 4,32 & 4,27 \\
Germany & 3,40 & 3,17 & 3,17 & 3,26 & 3,31 & 3,22 & 3,27 & 3,20 & 3,16 & 3,21 \\
Denmark & 3,51 & 3,44 & 3,43 & 3,44 & 3,95 & 3,98 & 4,48 & 4,64 & 4,53 & 4,53 \\
Finland & 4,69 & 5,24 & 5,35 & 5,51 & 5,33 & 4,74 & 4,79 & 5,42 & 5,44 & 5,49 \\
France & 7,92 & 8,03 & 8,04 & 7,90 & 7,90 & 8,54 & 8,14 & 8,11 & 7,95 & 7,97 \\
Greece & 23,13 & 24,04 & 23,20 & 23,91 & 25,36 & 28,02 & 27,88 & 27,30 & 26,38 & 28,33 \\
Croatia & 38,60 & 39,38 & 38,10 & 39,07 & 40,33 & 35,69 & 37,32 & 37,59 & 36,85 & 38,58 \\
Hungary & 6,15 & 5,92 & 5,56 & 5,75 & 6,09 & 6,33 & 6,73 & 6,85 & 7,14 & 7,58 \\
Ireland & 3,94 & 4,11 & 3,94 & 4,11 & 3,90 & 3,23 & 3,48 & 3,51 & 3,24 & 2,95 \\
Luxembourg & 5,27 & 5,37 & 5,24 & 4,91 & 4,59 & 5,14 & 5,19 & 4,88 & 4,89 & 4,68 \\
Poland & 5,16 & 5,12 & 5,31 & 5,11 & 4,96 & 4,77 & 4,86 & 4,87 & 4,80 & 4,75 \\
Portugal & 18,03 & 17,37 & 17,67 & 17,68 & 18,81 & 19,54 & 20,70 & 22,66 & 23,04 & 23,61 \\
Romania & 3,04 & 2,97 & 2,98 & 3,02 & 2,88 & 3,03 & 3,15 & 3,98 & 3,84 & 4,20 \\
Slovakia & 3,43 & 3,02 & 2,78 & 2,93 & 2,86 & 3,11 & 3,39 & 3,35 & 3,29 & 3,46 \\
Slovenia & 9,08 & 8,41 & 8,23 & 8,27 & 8,05 & 7,82 & 7,82 & 7,55 & 7,35 & 7,14 \\
\hline \multicolumn{1}{c}{ Sources }
\end{tabular}

Sources: developed by the author based on (The World Bank, 2019).

It is necessary first to carry out a correlation analysis, preliminary checking the correspondence of the studied indicators to the normal distribution law via the Shapiro-Wilk test (Shapiro and Wilk, 1965). It would confirm (or refute) the hypothesis about the positive impact of tourism development indicators (the number of tourists arriving and the number of departures within international tourism, as well as the share of tourism receipts in total exports) on the country's economic growth (annual GDP per capita growth). Calculations are made in the STATA software package. Table 6 presents the test results. According to the results of the Shapiro-Wilk test, the method for calculating the correlation coefficient is determined: 
A. Azizov. Innovation Development and Entrepreneurship Management in Tourism of Azerbaijan: Current Trends and Priorities

Pearson - the result of the Shapiro-Wilk test> 0.05 (Pearson, 1896); Spearman - the result of the ShapiroWilk test $<0.05$ (Spearman, 1904).

Table 6. Fragment of the Shapiro-Wilk test for the subordination of tourism development indicators to the normal distribution law

\begin{tabular}{lccccc}
\hline Country & Indicator & W & V & Z & Prob > z \\
\hline Azerbaijan & IT_AR & 0.95389 & 0.711 & -0.567 & 0.71464 \\
& IT_D & 0.94018 & 0.922 & -0.138 & 0.55499 \\
Belgium & IT_EX & 0.93846 & 0.948 & -0.090 & 0.53597 \\
& IT_AR & 0.89538 & 1.612 & 0.860 & 0.19482 \\
\multirow{3}{*}{ Bulgaria } & IT_D & 0.95086 & 0.757 & -0.464 & 0.67863 \\
& IT_EX & 0.76586 & 3.608 & 2.538 & $0.00557^{*}$ \\
\multirow{3}{*}{ Cyprus } & IT_AR & 0.86516 & 2.078 & 1.355 & 0.08776 \\
& IT_D & 0.84877 & 2.331 & 1.588 & 0.05617 \\
\multirow{3}{*}{ Czechia } & IT_EX & 0.80336 & 3.030 & 2.146 & $0.01593^{*}$ \\
& IT_AR & 0.81791 & 2.806 & 1.979 & $0.02391^{*}$ \\
& IT_D & 0.89733 & 1.582 & 0.825 & 0.20473 \\
& IT_EX & 0.95282 & 0.727 & -0.530 & 0.70197 \\
& IT_AR & 0.97306 & 0.415 & -1.390 & 0.91771 \\
& IT_D & 0.88476 & 1.776 & 1.045 & 0.14791 \\
& IT_EX & 0.84298 & 2.420 & 1.666 & $0.04790^{*}$ \\
\hline
\end{tabular}

${ }^{*}$ - indicators do not obey the normal distribution law; IT_AR - the indicator of the number of tourists arriving in the country; IT D - the indicator of the number of departures within the framework of international tourism; IT EX the indicator of receipts from tourism services in the country's total export.

Sources: developed by the author in the STATA 14.2 software package.

In addition, the approximation of the obtained results to the realities of the country's development determines the feasibility of defining the correlation coefficients, considering time lags to increase their adequacy level (Table 7).

Table 7. Estimation of the impact of tourism development indicators on the growth of GDP per capita in Azerbaijan and EU countries

\begin{tabular}{lcccccc}
\hline \multirow{2}{*}{ Country } & \multicolumn{2}{c}{ IT_AR } & \multicolumn{2}{c}{ IT_D } & \multicolumn{2}{c}{ IT_EX } \\
\cline { 2 - 7 } & Coefficient & $\begin{array}{c}\text { Time lag, } \\
\text { years }\end{array}$ & Coefficient & $\begin{array}{c}\text { Time lag, } \\
\text { years }\end{array}$ & $\begin{array}{c}\text { Coefficient } \\
\text { Time lag, } \\
\text { years }\end{array}$ \\
\hline Azerbaijan & $\mathbf{2}$ & $\mathbf{3}$ & $\mathbf{4}$ & $\mathbf{5}$ & $\mathbf{6}$ & $\mathbf{7}$ \\
Belgium & 0.7225 & 1 & -0.7403 & 3 & -0.5152 & 0 \\
Bulgaria & 0.5734 & 3 & 0.7717 & 1 & -0.5000 & 3 \\
Cyprus & 0.6720 & 0 & 0.7416 & 0 & -0.6786 & 0 \\
Czechia & 0.4643 & 0 & 0.4831 & 0 & 0.8784 & 3 \\
Germany & 0.5518 & 2 & -0.7483 & 3 & -0.6429 & 1 \\
Denmark & -0.5631 & 0 & -0.4314 & 2 & 0.8359 & 1 \\
Finland & 0.6199 & 0 & 0.5926 & 1 & 0.6847 & 0 \\
France & -0.8221 & 2 & 0.8108 & 0 & 0.5357 & 3 \\
Greece & 0.8773 & 3 & 0.6429 & 0 & 0.6786 & 2 \\
Croatia & 0.7995 & 0 & 0.7744 & 0 & 0.7700 & 0 \\
Hungary & 0.9634 & 0 & -0.9075 & 0 & -0.5919 & 0 \\
Ireland & 0.7047 & 0 & 0.8214 & 0 & 0.7395 & 0 \\
Luxembourg & 0.3639 & 0 & -0.3187 & 3 & -0.4995 & 0 \\
Poland & 0.4569 & 1 & 0.6654 & 2 & 0.5623 & 3 \\
Portugal & 0.9171 & 2 & 0.3296 & 2 & -0.6417 & 0 \\
\hline
\end{tabular}


A. Azizov. Innovation Development and Entrepreneurship Management in Tourism of Azerbaijan: Current Trends and Priorities

\begin{tabular}{|c|c|c|c|c|c|c|}
\hline & & & & & \multicolumn{2}{|c|}{ Continued Table 7} \\
\hline 1 & 2 & 3 & 4 & 5 & 6 & 7 \\
\hline Romania & 0.6281 & 0 & 0.5357 & 0 & 0.6786 & 1 \\
\hline Slovakia & 0.3195 & 2 & -0.4301 & 2 & 0.4454 & 0 \\
\hline Slovenia & 0.6952 & 0 & 0.6596 & 0 & -0.8549 & 2 \\
\hline
\end{tabular}

*IT_AR - IT AR - the indicator of the number of tourists arriving in the country; IT_D - the indicator of the number of departures within the framework of international tourism; IT_EX - the indicator of the receipts from the tourism services in the country's total export.

Sources: developed by the author in the STATA 14.2 software package.

The obtained results allow concluding a direct (positive) relationship between economic growth and the number of tourists arriving in the country (17 out of 19 countries), as evidenced by the sign of the correlation coefficient. This relationship is statistically significant. The level of strength is high/very high in 15 out of 19 countries (the correlation coefficient exceeds 0.5 ), the average - in 4 out of 19 countries (the correlation coefficient is from 0.3 to 0.5 ). The relationship between economic growth and international departures is positive in 13 of the 19 countries with high and medium strengths. Similarly, a direct relationship was observed between economic growth and tourism receipts in the export of countries with high and medium strength of the relationship in 11 of the 19 countries in the sample. At the same time, based on the national peculiarities of these countries' development, the analyzed effect is observed with different time lags from 0 to 3 years. The Bond linear dynamic panel-data estimation (Arellano - Bond linear dynamic regression model) was constructed to estimate and formalize the effect under study (Arellano and Bond, 1991; Arellano, 1987). This type of model includes the lags of the dependent variable as covariates and accounts for unnoticed fixed or random panel-level effects, given the history of past influence made by regressors on the current situation. The generalized method of moments (GMM) was used to obtain adequate estimates in the dynamic model. Before building the model, the variables expressed in natural logarithms of the studied indicators (tables 2-5) would be generated based on their different dimensions, and thus increasing the model quality. The Arellano-Bond model allows considering that some variables are not entirely exogenous. They could be influenced by the past and the present value of the dependent variable (dynamics of GDP per capita). In this case, the exogenous variable could be the number of tourists arriving, the rest - endogenous. Table 8 presents the results of assessing the impact of changes in the number of tourists' arrivals, the number of flights within international tourism, and the share of the revenue from tourism in total exports on the annual growth of GDP per capita.

The value of the Wald test Prob $>$ chi2 $=0.0000$ indicates the sufficiency of the model. Significance level $\mathrm{P}>|\mathrm{z}|$ of certain coefficients do not exceed 0.05 (the corresponding values are highlighted in bold; based on them, the hour lag is also determined). In addition, it is necessary to conduct a Sargan test of overidentifying restrictions to confirm the quality of the model. The test results are as follows:

. estat sarg

Sargan test of overidentifying restrictions

$\mathrm{HO}$ : overidentifying restrictions are valid

chi2(59) $=58.15699$

Prob $>$ chi2 $=0.5066$

According to the Sargan test, the recommended p-value should be at least $5 \%$ (in this case, the null hypothesis could not be rejected). In this study, Prob> chi2 $=0.5066$ corresponds to the specified condition. 
A. Azizov. Innovation Development and Entrepreneurship Management in Tourism of Azerbaijan: Current Trends and Priorities

Table 8. Results of assessing the impact of changes in tourism development indicators on economic growth in Azerbaijan and EU countries (dynamic regression model for assessing panel data of Arellano-Bond)

\begin{tabular}{|c|c|c|c|c|c|c|c|}
\hline \multicolumn{2}{|l|}{$\operatorname{lnGDP}$} & Coef. & Std. Err. & Z & $P>|z|$ & \multicolumn{2}{|c|}{ [95\% Conf. Interval] } \\
\hline $\begin{array}{ll}\ln G D P & \mathrm{~L} 1\end{array}$ & & -.1481649 & .1084135 & -1.37 & 0.172 & -.3606514 & .0643216 \\
\hline & L2 & -.2803732 & .0698356 & -4.01 & 0.000 & -.4172486 & -1434979 \\
\hline InIT_AR LO & & 3.380443 & 1.459552 & 2.32 & 0.021 & .519773 & 6.241113 \\
\hline & L1 & -2.346112 & 1.590731 & -1.47 & 0.140 & -5.463888 & .7716647 \\
\hline & L2 & .9153085 & 1.202907 & 0.76 & 0.447 & -1.442346 & 3.272963 \\
\hline InIT_D & & 1.331331 & .5896764 & 2.26 & 0.024 & .1755862 & 2.487075 \\
\hline & L1 & .4146616 & .6213312 & -0.67 & 0.505 & -1.632448 & .8031252 \\
\hline & L2 & .2953654 & .5707189 & -0.52 & 0.605 & -1.413954 & .8232231 \\
\hline InIT_EX LO & & -3.289117 & 1.363396 & -2.41 & 0.016 & -5.961325 & -.6169092 \\
\hline & L1 & 3.636622 & 1.39846 & 2.60 & 0.009 & .8956914 & 6.377552 \\
\hline & L2 & -1.641315 & .972554 & -1.69 & 0.091 & -3.547486 & .2648555 \\
\hline Const. & & -39.25169 & 11.09649 & -3.54 & 0.000 & -61.0004 & -17.50298 \\
\hline
\end{tabular}

${ }^{*}$ Coef. - estimates of the coefficients $\beta$; Std. Err. - standard deviations of estimates; $z$ - z-test; $P$ is the level of significance; Conf. Interval - confidence interval; Const. - constant; GDP - the indicator of the annual growth of GDP per capita; IT_AR - the indicator of the number of tourists arriving in the country; IT_D - the indicator of the number of departures within the framework of international tourism; IT_EX - the indicator of the receipts from the tourism services in the total export of the country; L0, L1, L2 - time lags 0,1 and 2 years, respectively.

Sources: developed by the author in the STATA 14.2 software package.

So, the constructed regression equation for the Arellano - Bond dynamic panel data estimation model has the following form:

$$
\begin{aligned}
& \operatorname{lnGDP} i, t=-39.25-0,28 \ln G D P i, t-2+3,38 \ln I T_{-} A R i, t+1,33 \ln I T_{-} D i, t+ \\
& 3,64 \ln I T_{-} E X i, t-1,
\end{aligned}
$$

where $\mathrm{i}$ - number of observations $(1, \ldots, \mathrm{N}) ; \mathrm{t}$ - indicator of time $\left(1, \ldots, \mathrm{T}_{\mathrm{i}}\right)$.

It has been empirically confirmed that the $1 \%$ rise in the number of tourists arriving in the country leads to an increase in the GDP per capita on average by $3.38 \%$. An increase in the number of departures within international tourism by $1 \%$ causes an increase in the GDP per capita on average by $1.33 \%$. The growth of the receipts from international tourism in total exports by $1 \%$ leads to the GDP per capita growth by an average of 3.64\%. These results are adequate for Azerbaijan and the EU countries included in the study sample. Particular attention should be paid to the Travel \& Tourism Competitiveness Index (TTCI), calculated by the World Economic Forum (WEF). In 2019 Azerbaijan was 71 out of 140 countries (the last rating was published for 2019, published once every two years). At the same time, despite the relatively low result in comparison with the highly developed countries of the world and the EU countries, Azerbaijan is ahead of many post-Soviet countries, for example, Ukraine (78th place), Armenia (79th place), Kazakhstan (80th place), Moldova (103rd place), Tajikistan (104th place) (WEF, 2019). Figure 1 demonstrates the dynamics of changes in the Competitiveness Index of Azerbaijan's tourism and travel sector and the country's place in the ranking for 2009-2019. 
A. Azizov. Innovation Development and Entrepreneurship Management in Tourism of Azerbaijan: Current Trends and Priorities

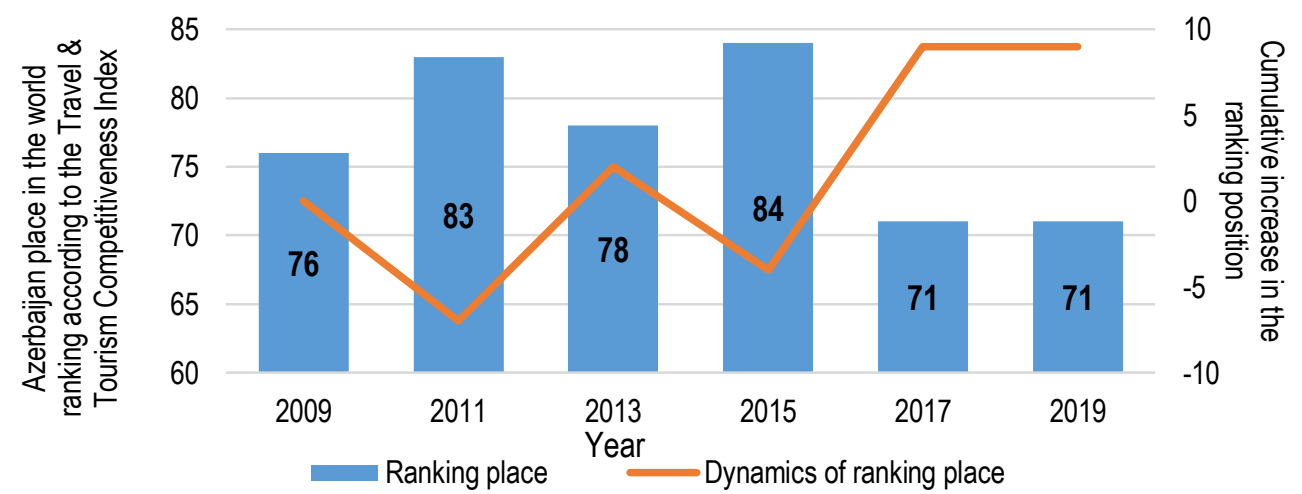

Figure 1. Dynamics of changes in the Travel \& Tourism Competitiveness Index of Azerbaijan and the country's place in the ranking for 2009-2019

Sources: developed by the author based on (WEF, 2009-2019).

The trend is mixed, characterized by ups and downs. There is a stable level at this stage (last 4 years).

One of the above-presented rating components is the country's readiness for information and communication technologies - ICT (ICT readiness). This component measures how advanced the ICT infrastructure in a country is and how widely individuals and businesses use it. Hong Kong, Denmark, and Sweden are the leaders in this indicator. Azerbaijan ranked 61st out of 140 countries in ICT readiness with an index of 5.0 (WEF, 2019). Figure 2 shows the analysis of the dynamics of changes in Azerbaijan's ICT readiness indicator and the country's place in the ranking for 2009-2019.

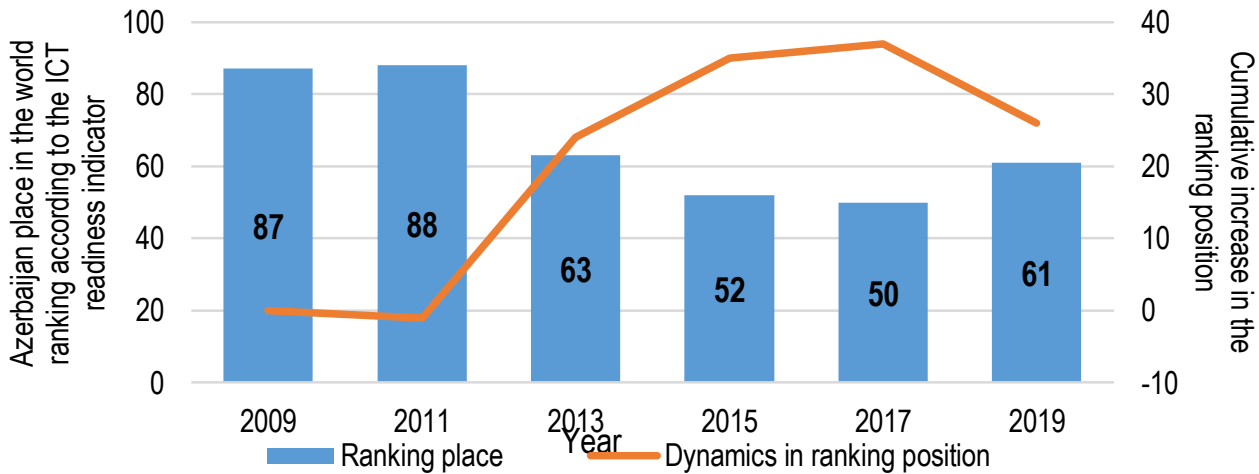

Figure 2. Dynamics of changes in Azerbaijan's ICT readiness indicator and the country's place in the ranking for 2009-2019

Sources: compiled by the author based on (WEF, 2009-2019).

The study compares the Competitiveness Index of the tourism and travel sector and the ICT readiness indicator as to its component. Therefore, the drop in the ICT readiness indicator hinders further improvement of the position in the competitiveness rating of the tourism and travel sector. In particular, the drop in the ICT readiness indicator over the past two years, along with other factors, led to the end of the growing trend of the index in 2019 in Azerbaijan.

For confirming this hypothesis, the Pearson correlation coefficient (Pearson, 1896) was calculated with a preliminary Shapiro-Wilk test (Shapiro and Wilk, 1965) for obeying the normal distribution law (Prob> z 
A. Azizov. Innovation Development and Entrepreneurship Management in Tourism of Azerbaijan: Current Trends and Priorities

$=0.1376>0.05)$ and considering possible time lag using the STATA software. The correlation coefficient ( 0.65 with a time lag of 2 years) indicates a close (high correlation strength) and positive relationship between the ICT readiness and the Competitiveness Index of the tourism and travel sector. It means that with an increase in Azerbaijan's ICT readiness, the competitiveness level of the tourism and travel sector of Azerbaijan will increase with a time lag of 2 years. The reliability of this hypothesis on a sample of 27 EU countries was checked, considering the possible positive impact of countries' ICT readiness and innovative development (based on the Global Innovation Index data (GII)) on the level of competitiveness of the tourism and travel sectors in the EU countries. Table 9 presents these samples.

Table 9. Comparative analysis on the positioning of Azerbaijan and the EU countries in international rankings according to the Tourism \& Travel Competitiveness Index and the Global Innovation Index

\begin{tabular}{lcccccc}
\hline \multicolumn{1}{c}{ Country } & $\begin{array}{c}\text { TTCl 2019 } \\
\text { place }\end{array}$ & $\begin{array}{c}\text { TTCl 2019 } \\
\text { score }\end{array}$ & $\begin{array}{c}\text { ICT 2019 } \\
\text { place }\end{array}$ & $\begin{array}{c}\text { ICT 2019 } \\
\text { score }\end{array}$ & $\begin{array}{c}\text { GII 2019 } \\
\text { place }\end{array}$ & $\begin{array}{c}\text { GII 2019 } \\
\text { score }\end{array}$ \\
\hline Spain & 1 & 5,4 & 27 & 5,8 & 29 & 47,85 \\
France & 2 & 5,4 & 20 & 5,9 & 16 & 54,25 \\
Germany & 3 & 5,4 & 19 & 6,0 & 9 & 58,19 \\
Italy & 8 & 5,1 & 41 & 5,5 & 30 & 46,30 \\
Austria & 11 & 5,0 & 16 & 6,1 & 21 & 50,94 \\
Portugal & 12 & 4,9 & 38 & 5,5 & 32 & 44,65 \\
Netherlands & 15 & 4,8 & 9 & 6,3 & 4 & 61,44 \\
Denmark & 21 & 4,6 & 2 & 6,4 & 7 & 58,44 \\
Sweden & 22 & 4,6 & 3 & 6,4 & 2 & 63,65 \\
Luxembourg & 23 & 4,6 & 11 & 6,2 & 18 & 53,47 \\
Belgium & 24 & 4,5 & 23 & 5,8 & 23 & 50,18 \\
Greece & 25 & 4,5 & 51 & 5,2 & 41 & 38,90 \\
Ireland & 26 & 4,5 & 30 & 5,7 & 12 & 56,10 \\
Croatia & 27 & 4,5 & 54 & 5,2 & 44 & 37,82 \\
Finland & 28 & 4,5 & 13 & 6,1 & 6 & 59,83 \\
Malta & 35 & 4,4 & 25 & 5,8 & 27 & 49,01 \\
Slovenia & 36 & 4,3 & 42 & 5,5 & 31 & 45,25 \\
Czechia & 38 & 4,3 & 32 & 5,7 & 26 & 49,43 \\
Poland & 42 & 4,2 & 40 & 5,5 & 39 & 41,31 \\
Cyprus & 44 & 4,2 & 21 & 5,9 & 28 & 48,34 \\
Bulgaria & 45 & 4,2 & 73 & 5,2 & 40 & 40,35 \\
Estonia & 46 & 4,2 & 14 & 6,1 & 24 & 49,97 \\
Hungary & 48 & 4,2 & 47 & 5,3 & 33 & 44,51 \\
Latvia & 53 & 4,0 & 31 & 5,7 & 34 & 43,23 \\
Romania & 56 & 4,0 & 55 & 5,2 & 50 & 36,76 \\
Lithuania & 59 & 4,0 & 35 & 5,6 & 38 & 41,46 \\
Slovakia & 60 & 4,0 & 33 & 5,7 & 37 & 42,05 \\
Azerbaijan & 71 & 3,8 & 61 & 5,0 & 84 & 30,21 \\
\hline
\end{tabular}

${ }^{*}$ TTCl - Tourism and Travel Sector Competitiveness Index, ICT - ICT Readiness Indicator (a component of Tourism and Travel Sector Competitiveness Index), GII - Global Innovation Index.

Sources: developed by the author based on (WEF, 2019; WIPO, 2019).

One should note that Switzerland, Sweden, and the United States are leaders in the Global Innovation Index in 2020 (WIPO, 2020). Figure 3 shows the analysis of the change dynamics in the Global Innovation Index of Azerbaijan and the country's place in the ranking for 2011-2020. 
A. Azizov. Innovation Development and Entrepreneurship Management in Tourism of Azerbaijan: Current Trends and Priorities

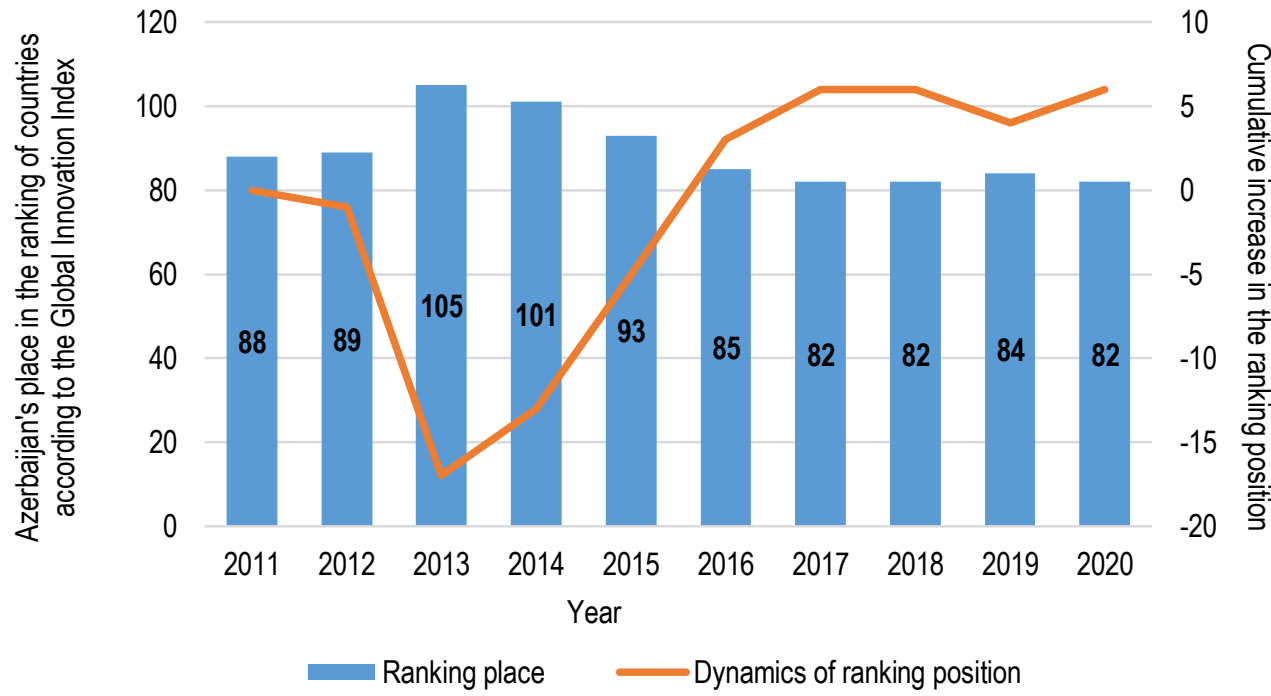

Figure 3. Dynamics of changes in the Global Innovation Index of Azerbaijan and the country's place in the ranking for 2011-2020

Sources: developed by the author based on (WIPO, 2011-2020).

Azerbaijan ranks 82 nd out of 131 countries. The dynamics of the last five years are characterized by insignificant changes in the rating by two positions in different directions.

Table 10 presents the Shapiro-Wilk test results (Shapiro \& Wilk, 1965) on obedience to the normal distribution law of countries' ICT readiness, the level of innovative development, and the calculation of correlation coefficients (Spearman, 1904; Pearson, 1896).

Table 10. Results of the correlation analysis of the ICT readiness impact and the innovation development level on the competitiveness of the tourism and travel sector in the EU countries and Azerbaijan

\begin{tabular}{|c|c|c|c|c|}
\hline Indicator & $\begin{array}{l}\text { Shapiro-Wilk test } \\
\text { result }\end{array}$ & $\begin{array}{c}\text { Correlation } \\
\text { coefficient } \\
\text { calculation method }\end{array}$ & $\begin{array}{l}\text { Correlation } \\
\text { coefficient }\end{array}$ & Description \\
\hline $\begin{array}{l}\text { ICT Readiness } \\
\text { (Azerbaijan) }\end{array}$ & $\begin{aligned} \text { Prob }>z & =0.1376 \\
& >0.05\end{aligned}$ & Pearson & $\begin{array}{c}0.65 \\
\text { (with a time lag of } 2 \\
\text { years) }\end{array}$ & $\begin{array}{l}\text { Straight } \\
\text { (positive) }\end{array}$ \\
\hline $\begin{array}{l}\text { ICT readiness } \\
\text { (sample from } \\
28 \text { countries) }\end{array}$ & $\begin{aligned} \text { Prob }>z & =0.8108 \\
& >0.05\end{aligned}$ & Pearson & $\begin{array}{c}0.46 \\
\text { (no lag in time) }\end{array}$ & $\begin{array}{l}\text { Average strength } \\
\text { Straight } \\
\text { (positive) }\end{array}$ \\
\hline $\begin{array}{l}\text { Global Innovation Index } \\
\text { (Azerbaijan) }\end{array}$ & $\begin{aligned} \text { Prob }>z & =0.5714 \\
& >0.05\end{aligned}$ & Pearson & $\begin{array}{c}0.33 \\
\text { (without lag in time) }\end{array}$ & $\begin{array}{l}\text { Average strength } \\
\text { Straight } \\
\text { (positive) }\end{array}$ \\
\hline $\begin{array}{l}\text { Global Innovation Index } \\
\text { (sample from } \\
28 \text { countries) }\end{array}$ & $\begin{aligned} \text { Prob }>z & =0.0293 \\
& <0.05\end{aligned}$ & Spearman & $\begin{array}{c}0.60 \\
\text { (no lag in time) }\end{array}$ & $\begin{array}{l}\text { High strength } \\
\text { Straight } \\
\text { (positive) }\end{array}$ \\
\hline
\end{tabular}

Sources: developed by the author using software STATA. 
A. Azizov. Innovation Development and Entrepreneurship Management in Tourism of Azerbaijan: Current Trends and Priorities

The results of the correlation analysis empirically confirm the hypothesis that with an increase in the ICT readiness and innovative development of EU countries, the competitiveness level of the tourism and travel sector will also increase. At the same time, in Azerbaijan, an increase in the degree of ICT readiness leads to a rise in tourism's competitiveness with a time lag of 2 years (the level of the relationship strength between the indicators is relatively higher). In turn, the innovative development growth increases tourism competitiveness without a lag in time (the level of the relationship strength between the indicators is comparatively lower).

A regression analysis was carried out to formalize the impact of the ICT and the innovative development readiness of the EU countries and Azerbaijan (a sample of 28 countries) on the competitiveness level of the tourism and travel sector (Table 11).

Table 11. Results of regression analysis regarding the impact of ICT and the innovation development readiness of the EU countries and Azerbaijan on the competitiveness of the tourism and travel sector

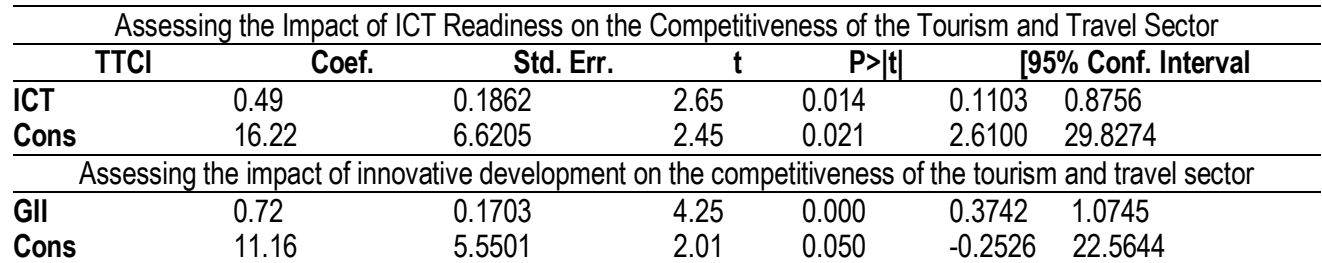

${ }^{*}$ TTCI - Tourism and Travel Sector Competitiveness Index; ICT - an indicator of ICT readiness; GII - Global Innovation Index; Coef. - estimates of the $\beta$ coefficients obtained by the least squares method; Std. Err. -Standard deviations of estimates; $\mathrm{t}$ - $\mathrm{t}$-statistics; $\mathrm{P}$ - the significance level of the t-criterion; Conf. Interval - confidence interval; Cons - a constant.

Sources: developed by the author using STATA software.

The significance level of the t-test does not exceed 0.05 for all coefficients of the models. Therefore, they could be considered statistically significant (the probability of an erroneous hypothesis is from 0 to $5 \%)$. The determination coefficients in the R-squared models are low ( 0.21 and 0.41 , respectively). It is explained by including a factor indicator in the model at this stage. Significance levels Prob> $F$ of the models ( 0.01 and 0.0002 , respectively) indicate the adequacy of the constructed linear regression models:

$$
\begin{aligned}
& \text { TTCI }=0,49 I C T+16,22 \\
& \text { TTCI }=0,72 \text { GII }+11,16
\end{aligned}
$$

The results from the formalization of the studied influence led to the conclusion that with an increase in the country's ICT readiness (expressed by the corresponding indicator) by $1 \%$, the competitiveness level of the country's tourism and travel sector (represented by the index of the same name) would increase by an average of $0.49 \%$. In turn, an increase in the country's innovation development (expressed by the Global Innovation Index) by $1 \%$ would lead to a rise in the competitiveness level of the country's tourism and travel sector (described by the index of the same name) by an average of $0.72 \%$. It means that the governments of the EU countries and Azerbaijan, as well as other stakeholders, should not dwell only on innovations in ICT in the field of tourism, paying more attention to financial, insurance, marketing, administrative, management, medical, socio-cultural, environmental and other innovations, which are closely related and complement each other. 
Conclusions. A study described the current state of entrepreneurship in tourism in Azerbaijan, the EU countries, and general. Attention is focused on the negative consequences of the COVID-19 pandemic for this sphere of economic activity and, accordingly, on the need to follow the trends of innovative development and digitalization, effective management and managerial innovations, a social partnership of various stakeholders on the path to achieving sustainable and competitive tourism, as well as on the increasing role of the state and possible forms of support. The positive economic effect from entrepreneurship development in the tourism sector in Azerbaijan and the EU countries has been found based on the correlation and regression analysis (Arellano-Bond dynamic regression model for evaluating panel data). It has been empirically confirmed that the $1 \%$ growth of the number of tourists arriving in the country increases the growth rate of GDP per capita by an average of 3.38\%; the number of departures within international tourism - by $1.33 \%$, the share of receipts from international tourism in total exports by $3.64 \%$, respectively. It was found that the competitiveness of the tourism services sector directly depends on the country's innovation development and the tourism digitalization, in particular, ICT readiness (in Azerbaijan, the effect of improving ICT readiness is achieved longer than in the EU countries, with a 2-year lag in time). It has been empirically confirmed that $1 \%$ growth of the country's ICT readiness contributes to a rise in tourism competitiveness in Azerbaijan and the EU countries by an average of $0.49 \%$; in the level of innovation development - by $0.72 \%$. Thus, the governments of Azerbaijan and the EU countries and other stakeholders (business, investors, start-ups, etc.) should not be limited only to ICT and digitalization to develop entrepreneurship in tourism effectively. Nowadays, it is undeniably a priority, but at the same time, they should increase the level of innovation development in the country, covering other trend areas (financial, insurance, marketing, managerial, administrative, medical, socio-cultural, environmental, and other innovations).

Funding: This research received no external funding.

\section{References}

Arellano, M. (1987). Computing robust standard errors for within-groups estimators. Oxford bulletin of Economics and Statistics, 49(4), 431-434. [Google Scholar]

Arellano, M., \& Bond, S. (1991). Some tests of specification for panel data: Monte Carlo evidence and an application to employment equations. The review of economic studies, 58(2), 277-297. [Google Scholar] [CrossRef]

Ateljevic, J., \& Page, S. . (2009). Tourism Entrepreneurship - Concepts and Issues. Tourism and Entrepreneurship: International Perspectives, 480 p. (Chapter 2, p. 9-32). [CrossRef]

ATTA. (2019). Adventure Tourism Development Index. Retrieved from [Link]

Boronos, V., Zakharkin, O., Zakharkina, L., \& Bilous, Y. (2020). The Impact of the COVID-19 Pandemic on Business Activities in Ukraine. Health Economics and Management Review, 1(1), 76-83. [Google Scholar] [CrossRef]

Bouronikos, V. (2021). How Digital Technology in Tourism is Affecting the Way we Travel. Institute of Entrepreneurship Development. Retrieved from [Link]

Comerio, N., \& Strozzi, F. (2019). Tourism and its Economic Impact: A Literature Review Using Bibliometric Tools. Tourism Economics, 25(1), 109-131. [Google Scholar] [CrossRef]

Das, K. S., \& Naskar, K. (2018). Nexus between Infrastructure and Tourism Development. SocioEconomic Challenges, 2(2), 612. [CrossRef]

Dehtjare, J. (2018). Digital Technologies in Tourism-a Key to Competence. Conference: Business Competences. ISMA, Riga, Latvia. Retrieved from [Link]

George, B. (2020). Inclusive Sustainable Development in the Caribbean Region: Social Capital and the Creation of Competitive Advantage in Tourism Networks. Business Ethics and Leadership, 4(3), 119-126. [Google Scholar] [CrossRef]

Hallak, R., Assaker, G., \& Lee, C. (2015). Tourism Entrepreneurship Performance: The Effects of Place Identity, Self-Efficacy, and Gender. Journal of Travel Research, 54(1), 36-51. [Google Scholar] [CrossRef]

Işık, C., Günlü Küçükaltan, E., Kaygalak Çelebi, S., Çalkın, Ö., Enser, İ. \& Çelik, A. (2019). Tourism and entrepreneurship: A literature review. Journal of Ekonomi, 1 (1), 1-27. [Google Scholar]

Jaafar, M., Abdul-Aziz, A. R., Maideen, S. A., \& Mohd, S. Z. (2011). Entrepreneurship in the Tourism Industry: Issues in Developing Countries. International Journal of Hospitality Management, 30(4), 827-835. [Google Scholar] [CrossRef] 


\section{A. Azizov. Innovation Development and Entrepreneurship Management in Tourism of Azerbaijan: Current Trends and}

Priorities

Karaoulanis, A., \& Vasiliki, K. (2018). Tourism In Developing Countries. The Path Towards Sustainable Development and its Interaction with the Local Communities, The Environment, and the Human Factor. SocioEconomic Challenges, 4(2), 80-86. [Google Scholar] [CrossRef]

Khan, M. Y. H., Hossain, A. (2018). The Effect of Ict Application On The Tourism And Hospitality Industries In London. SocioEconomic Challenges, 4(2), 60-68. [Google Scholar] [CrossRef]

Khurramov, O. K. (2020) The Role of the Tourism Sector in the Digitalization of the Service Economy. Economics and Innovative Technologies, 1 (6), 1-8. [Google Scholar]

Revfine. (n.d.). 11 Key Technology Trends Emerging in the Travel \& Tourism Industry. Retrieved from [Link]

Letunovska, N., Kwilinski, A., \& Kaminska, B. (2020). Scientific research in the health tourism market: a systematic literature review. Health Economics and Management Review, 1, 8-19. [Google Scholar] [CrossRef]

Lordkipanidze, M., Brezet, H., \& Backman, M. (2005). The entrepreneurship factor in sustainable tourism development. Journal of cleaner production, 13(8), 787-798. [Google Scholar] [CrossRef]

Mofokeng, N. E. M., \& Matima, T. K. (2018). Future Tourism Trends: Virtual Reality Based Tourism Utilizing Distributed Ledger Technologies. African Journal of Hospitality, Tourism and Leisure, 7(3), 1-14. [Google Scholar]

Natocheeva, N., Shayakhmetova, L., Bekkhozhaeva, A., Khamikhan, N., \& Pshembayeva, D. (2020). Digital Technologies as a Driver for the Development of The Tourism Industry. In E3S Web of Conferences (Vol. 159, p. 04002). EDP Sciences. [Google Scholar] [CrossRef

Navickiene, R., Fominiene, V.B., Dias, F. (2015). Entrepreneurship in the Sustainable Tourism Sector. The Case of Tour Operators in Lithuania. Transformations in Business and Economics, 14(3), 138-153. [Google Scholar]

Opute, A. P., Irene, B. O., \& Iwu, C. G. (2020). Tourism Service and Digital Technologies: A Value Creation Perspective. African Journal of Hospitality, Tourism and Leisure, 9(2), 1-18. Retrieved from [Link]

Pearson, K. (1896). Mathematical contributions to the theory of evolution-III. Regression, heredity, and panmixia. Philosophical Transactions of the Royal Society of London, Series A 187, 253-318.[Google Scholar] [CrossRef]

Ratten, V. (2019). Tourism entrepreneurship research: a perspective article. Tourism Review, 75 (1), 122-125. [Google Scholar] [CrossRef]

Rubanov, P., \& Marcantonio, A. (2017). Alternative Finance Business-Models: Online Platforms. Financial Markets, Institutions and Risks, 1(3), 92-98. [Google Scholar] [CrossRef]

Saberifar, R., Chatterjee, U., Bhunia, G. S. (2019). Measuring the Level of Satisfaction with Respect to the Quality of Services Provided by the Local Tourist Destination in Mashhad, Iran. SocioEconomic Challenges, 3(1), 64-71. [Google Scholar] [CrossRef].

Schiopu, A. F., Vasile, D. C., \& Tuclea, C. E. (2015). Principles and best practices in successful tourism business incubators. Amfiteatru Economic Journal, 17(38), 474-487. [Google Scholar] []

Shapiro, S, \& Wilk, M. (1965). An analysis of variance test for normality (complete samples). Biometrika, 52, 591-611. [Google Scholar]

Solvoll, S., Alsos, G. A., \& Bulanova, O. (2015). Tourism Entrepreneurship - Review and Future Directions. Scandinavian Journal of Hospitality and Tourism, 15(1), 120-137. [Google Scholar] [CrossRef]

Spearman, C. E. (1904). The proof and measurement of association between two things. American Journal of Psychology, 15, 72-101. [Google Scholar]

Taliouris, E., Trihas, N. (2017). Public Policy for Corporate Social Responsibility and Governance for Sustainable Tourism

Development in Greece. Business Ethics and Leadership, 1(4), 49-57. [Google Scholar] [CrossRef]

The World Bank (2019). GDP per capita growth (annual \%). Retrieved from [Link]

The World Bank (2019). International tourism, number of arrivals. Retrieved from [Link]

The World Bank (2019). International tourism, number of departures. Retrieved from [Link]

The World Bank (2019). International tourism, receipts (\% of total exports).Retrieved from [Link]

Tiagoa, F., Gilb, A., Stembergerc, S., \& Borges-Tiagod, T. (2021). Digital sustainability communication in tourism. Journal of Innovation \& Knowledge, 6 (1), 27-34. [CrossRef]

Tiutiunyk, I., Humenna, Yu., \& Flaumer, A. (2021). Covid-19 impact on business sector activity in the EU countries: digital issues. Health Economics and Management Review, 2(1), 54-66. [Google Scholar] [CrossRef]

Tleuberdinova, A. (2021). Macro-economic Factors Influencing Tourism Entrepreneurship: The Case of Kazakhstan. The Journal of Entrepreneurship, 30(1), 179-209. [Google Scholar] [CrossRef]

UNDESA. (n.d.). Sustainable Development Goals. Retrieved from [Link

UNWTO. (2020). Tourism Data Dashboard. Retrieved from [Link]

WEF (2009). The Travel \& Tourism Competitiveness Report 2009. Geneva, Switzerland. Retrieved from [Link]

WEF (2011). The Travel \& Tourism Competitiveness Report 2011. Geneva, Switzerland. Retrieved from [Link]

WEF (2013). The Travel \& Tourism Competitiveness Report 2013. Geneva, Switzerland. Retrieved from [Link

WEF (2015). The Travel \& Tourism Competitiveness Report 2015. Geneva, Switzerland. Retrieved from [Link]

WEF (2017). The Travel \& Tourism Competitiveness Report 2017. Geneva, Switzerland. Retrieved from [Link

WEF (2019). The Travel \& Tourism Competitiveness Report 2019. Geneva, Switzerland. Retrieved from [Link]

WIPO (2011). Global Innovation Index 2011. Accelerating Growth and Development. Geneva, Switzerland. Retrieved from [Link WIPO (2012). Global Innovation Index 2012. Stronger Innovation Linkages for Global Growth. Geneva, Switzerland. Retrieved 
A. Azizov. Innovation Development and Entrepreneurship Management in Tourism of Azerbaijan: Current Trends and Priorities

from [Link]

WIPO (2013). Global Innovation Index 2013. The Local Dynamics of Innovation. Geneva, Switzerland. Retrieved from [Link]

WIPO (2014). Global Innovation Index 2014. The Human Factor in Innovation. Geneva, Switzerland. Retrieved from [Link]

WIPO (2015). Global Innovation Index 2015. Effective Innovation Policies for Development. Geneva, Switzerland. Retrieved

from: [Link]

WIPO (2016). Global Innovation Index 2016. Winning with Global Innovation. Geneva, Switzerland. Retrieved from [Link]

WIPO (2017). Global Innovation Index 2017. Innovation Feeding the World. 10th edition. Geneva, Switzerland. Retrieved from [Link]

WIPO (2018). Global Innovation Index 2018. Energizing the World with Innovation. 11th edition. Geneva, Switzerland. Retrieved from [Link]

WIPO (2019). Global Innovation Index 2019. Creating Healthy Lives-The Future of Medical Innovation. 12th edition. Geneva, Switzerland. Retrieved from [Link]

WIPO (2020). Global Innovation Index 2020. Who Will Finance Innovation? 13th edition. Geneva, Switzerland. Retrieved from [Link]

Wörndl, W., Koo, C., \& Stienmetz, J. L. (Eds.). (2021). Information and Communication Technologies in Tourism 2021: Proceedings of the ENTER 2021 ETourism Conference, January 19-22, 2021. Springer Nature. [Google Scholar] [CrossRef]

Zsarnoczky, M. (2018). The Digital Future of the Tourism \& Hospitality Industry. Boston Hospitality Review, 6, 1-9. [Google $\underline{\text { Scholar] }}$

Анар Алі огли Азізов, доктор філософрії з економіки, доцент, Азербайджанський університет кооперації, Азербайджан Інноваційний розвиток і менеджмент підприємництва у туризмі Азербайджану: сучасні тенденції та пріоритетні напрямки

У статті досліджено сучасні тенденції та пріоритетні напрямки інноваційного розвитку підприємництва в туризмі Азербайджану, враховуючи національні особливості та тренди туристичного ринку Європи. Автором проаналізовано значущість туризму, його доступність та соціально відповідальне підприємництво у сфері туристичних послуг у контексті сталого розвитку та досягнення його цілей. Обґрунтовано економічний ефект від розвитку туристичної сфери. У роботі виокремлено роль та ключові аспекти цифровізації туризму та управлінських інновацій у сфері туристичних послуг Результати систематизації наукових досліджень та напрацювань із зазначеної проблематики засвідчили відсутність єдиного підходу до оцінювання взаємозв'язків інноваційного розвитку підприємництва у туристичній сфері та макроіндикаторів країни. Головною метою статті $є$ дослідження впливу підвищення рівня розвитку туризму на економічне зростання та оцінка впливу інноваційної активності на конкурентоспроможність туристичної сфери (на основі аналізу досвіду країн ЄС та Азербайджану). інформаційною базою дослідження стали статистичні та аналітичні дані Світового банку, Світової організації інтелектуальної власності, Світової туристської організації, Світового економічного форуму. Для досягнення поставлених цілей у роботі проаналізовано основні тенденції ринку туристичних послуг. Для визначення сильних та слабких сторін, можливостей та загроз на ринку було проведено SWOT-аналіз. Схарактеризовано ключові напрями в менеджменті інноваційного розвитку підприємництва в туризмі, базуючись на твердженні про необхідність сприяння успішним інноваціям у туризмі та підприємницькій екосистемі шляхом взаємодії стейкхолдерів. Окрему увагу приділено зростаючій ролі держави у підвищенні інноваційної активності туристичного підприємництва, зокрема, в умовах негативних наслідків пандемії COVID-19. Побудовано динамічну регресійну модель оцінки панельних даних Ареллано-Бонда для емпіричного підтвердження та формалізації позитивного впливу підвищення рівня розвитку туризму (частка виручки від туристичних послуг у загальному експорті, число прибуваючих туристів та туристичних польотів) на економічне зростання країн ЄС та Азербайджану (приріст ВВП на душу населення). Перевірку якості моделі здійснено за допомогою тесту Саргану у програмному пакеті STATA 14.2 Взаємозв'язок досліджуваних показників попередньо охарактеризований за результатами кореляційиого аналізу (тест Шапіро-Вілка, розрахунок коефіцієнтів кореляції Пірсона/ Спірмена з часовими лагами). У ході дослідження проведено компаративний, кореляційний та регресійний аналізи впливу ступеня готовності країн $€ С$ та Азербайджану до інформаційнокомунікаційних технологій та рівня інноваційного розвитку загалом на рівень конкурентоспроможності туристичної сфери країн. За результатами дослідження автор приходить до висновку щодо необхідності доповнення інновацій в ІКТ у сфері туризму та його цифровізації, впроваджуючи фінансові, страхові, маркетингові, управлінські, адміністративні, медичні, соціокультурні, екологічні та інші інновації в туризмі, які сьогодні тісно взаємопов'язані та вигідно доповнюють одна одну.

Ключові слова: державна політика, інновації у туризмі, конкурентоспроможність туризму, менеджмент інновацій, підприємництво у туризмі, стійкий туризм, фінансування інновацій, цифровізація туризму. 